\title{
Real Estate Developers' Perception on Conventional Borrowing in Financing Residential Developments: A Review of Emerging Literature
}

\author{
Aliyu Ahmad Aliyu ${ }^{1}$, Hamza Usman ${ }^{1} \&$ Muktar Usman Alhaji ${ }^{2}$ \\ ${ }^{1}$ Department of Estate Management and Valuation, Faculty of Environmental Technology, Abubakar Tafawa \\ Balewa University, Bauchi, Bauchi State, Nigeria \\ ${ }^{2}$ Department of Estate Management and Valuation, School of Environmental Studies, The Federal Polytechnic, \\ Damaturu, Yobe State, Nigeria
}

Correspondence: Aliyu Ahmad Aliyu, Department of Estate Management and Valuation, Faculty of Environmental Technology, Abubakar Tafawa Balewa University, Bauchi, P.M.B. 0248, Bauchi, Bauchi State, Nigeria. E-mail: aaaliyu1978@gmail.com

Received: March 4, 2015

Accepted: March 30, 2015

Online Published: June 25, 2015

doi:10.5539/ijef.v7n7p240

URL: http://dx.doi.org/10.5539/ijef.v7n7p240

\begin{abstract}
In the midst of the tripartite essential needs of mankind is residence, often called shelter. This inevitability of man, which is affordable through real property development, is money exhaustive and entails huge and enormous finance which is, as a general rule, beyond the accomplishment of equity capital; consequently, the inevitability of borrowing to finance housing development. Nevertheless, this "supposed to be" complement of equity capital has proved insufficient and unsuccessful over time, owing to interest, non-affordability, stringent and rigorous repayment requirements and others, in financing housing developments in Nigeria. The purpose of this investigation is to appraise and assess the perception and opinion of real property developers with reference to conventional borrowing and its attendant consequences and repercussion in financing housing developments with a view to uncover the potentials of 'Sukuk' as an alternative source of financing housing developments in North-Eastern Nigeria. Based on the findings of existing literature, it is sufficed to state that the performance of conventional financial institutions in financing residential developments is very low; developers' perception about conventional borrowing and its associated terms considerably influence their intention and decision to borrow in financing residential developments; developers have high preference for 'Sukuk', when obtainable, than conventional source of financing residential developments. This research would provide the foundation whereupon policy makers would evaluate and appraise the existing financing strategy to mirror the desires, yearnings, aspirations and diversities of all citizens; it would expose the gap in financing residential developments, thereby providing both local and international investors the opportunity to tap from unutilized investment opportunity; it would also provide the basis for solving the seemingly intractable residential development financing problems in Nigeria. This research would be the first to evaluate real estate developers' perception on borrowing in financing residential developments in North-Eastern Nigeria and probably the first to apply the theory of planned behavior in the field of real estate development financing, at least in Nigeria.
\end{abstract}

Keywords: perception, property developers, real estate development, residential development finance and theory of planned behavior

\section{Introduction}

\subsection{Background of the Research}

In the midst of the tripartite essential needs of mankind, shelter occupies a central position. Subsequent to food, shelter is mainly the most imperative desire of man (Adedokun, Akinradewo, Adegoke, \& Abiola-Falemo, 2012; Udoekanem, 2012; Olurotimi, 2009; Sanusi, 2003, Ogbonna, 2012). A well habitable shelter ensures dwelling and lodging to the general public (Onyike, 2009). In addition to shelter, residential property or accommodation is not simply a mono-effect product; it is a long-lasting end user product that has a multiplier upshot on the, by and large, trade and industry growth as well as development of a nation (Ire-Okoli, 2012). Nevertheless, regardless of the momentous function played by shelter, Udo-Akagha (2000) stated that the provision of this indispensable 
commodity is insufficient and in short supply.

Lodging or dwelling is a creation or product of landed property or realty construction industry. Ire-Okoli (2012) stressed the fact that real property development gives a foundation for a country's economic growth and development all the way through contributing to country's Gross Domestic Product (GDP).

On the other hand, such input is at unstable extent. While urbanized and industrialized nations witnessed important contribution of landed property sector in their gross domestic product, the reverse is more often than not the case with emergent nations (Udoekanem, 2012). In his study of Dubai Economy, Ire-Okoli (2012) hypothesized that real property development thrived in transforming and converting Dubai economy into an essential business port and trade center, paving way to the country's economic and fiscal boom and certainly, one of the notably world' fastest and greatest growing economies. Landed property industry includes the activities and functions of two key players- the public or civic institutions and the private or individual sector. While, the volumes of housing accommodations are supplied by the individual or private sector, there is the need of former's involvement to offer favorable economic atmosphere as well as to provide framework and support for the latter's function and activities (Oluratimi, 2009). Although Udo-Akagho (2000) condemned and censured direct government involvement and intervention in providing residential accommodation, he conversely acknowledges and admits the need for public sector involvement in providing the conducive environment for individual or private sector partaking. Hence, these key players work harmoniously and mutually in concert for the development of housing sector.

The private sector plays a very important role in the development and growth of residential accommodations in each country. As a matter of fact, this sector is generally categorized into two: the corporate private developers and the private individual developers (Kuye, 2000). Whereas the former include those who build residential dwellings as an investment of which monetary return may perhaps be gained; the latter are more concern with social and collective consideration of lodging, status and prestige (Kuye, 2000; Udechukwu, 2006). It can be established that given that the intend of assuming title to housing accommodation, either through outright or absolute development or purchase, could be monetary or non-economic, fiscal or otherwise, those who develop or purchase their own lodging could be referred to as private individual developers, in any case for the sole act of residential development they contribute and participate in.

Realty development implies the incorporation of large capital sum injected into sequence of processes starting from site acquisition till completion (Nuhu, 2007; Lawal, 2000; Miles, Berens, Epph, \& Weiss, 2007). Furthermore, these processes are money intensive and involve huge capital. Therefore, finance is the pivot and the most significant instrument in real estate development (Ebie, 1998; Udo-Akagha, 2000; Alile, 2005; Sanusi, 2003; Ozili, 2009; Onyike, 2009; Udoekanem, 2012; Ibuoye, 2009; Ajibola, Oloyede, \& Oni, 2009; Aliyu, Kasim, \& Martin, 2011; etc). This finance, however, is sourced either via debt or equity or from both (leverage). Indeed, equity is raised through accrued individual savings. Though it played very important role in housing development; particularly to private individual developers, it is on the other hand insufficient and not enough, (Ibouye, 2009; Ogunba, 2009; Ajibola et al., 2009). Ajibola et al. (2009) revealed that the complex economic situation, the traditional settings and the requirement for enormous capital had made the issue of finance from informal evenhandedness or equity source disgustingly derisory for any significant landed property development. Upholding this, Ogunba (2009) stated that income in Nigeria is placed and ranked in the midst of the lowest in the globe. Consequently, this type of finance is mainly informal and insufficient, catering for the modern demands for residential accommodation today (Ibouye, 2009).

In line to complement equity, real estate developers resort and revert to borrowing in order to raise the much needed money for housing development (Ibouye, 2009; Aliyu et al., 2011; Ajibola et al., 2009). Mortgage and lending institutions, insurance companies, money deposit banks and pension funds are the chief source of conventional finance for landed property development. Conversely, these substitute sources to equity in financing housing developments proved abate in fulfilling the dwelling needs of Nigerians (Ajibola et al., 2009). The previous studies such as Aliyu et al. (2011), Ajibola et al. (2009), Udeokenam (2012), Sanusi (2003), Ebie (1998), Ibuoye (2012), and others ascribed the setback and failure to high interest rate, stringent repayment requirements inaccessibility to the fund, macro-economic environment cumbersome loan requirement, etc. The national housing fund (NHF), which was established in 1992 to generate fund from Nigerian who earns $\$ 3000$ and above monthly salary at $4 \%$ interest rate and spend it for mortgage financing, Ogunba (2009) realized that it has not made satisfactorily substantial and considerable impact in facilitating and enhancing housing financing in Nigeria.

Of major significance, although ignored, is the developers' discernment and perception toward borrowing and its 
negative consequences in financing housing accommodation. Based on the theory of planned behavior, as established by Ajzen (2002), individual action is shaped by three type of thought: behavioral belief, normative belief and control belief. In their particular aggregates, behavioral beliefs create a favorable or unfavorable approach toward the behavior. In contribution, outlook toward the behavior, perception of behavioral control and subjective norm culminate to formation and creation of a behavioral meaning. As a universal rule, the more constructive and favorable the attitude and subjective or slanted norm and the larger the apparent control, the stronger or greater should be the person's purpose to execute the behavior in tutor. As argued by Chiou (1998), the conjecture of planned behavior suggests that professed behavioral power of individual in decision making state of affairs may affect his behavioral objectives. Perception is more essential in affecting person's behavioral goal chiefly when the performance is not completely underneath volitional control. For example, this is effectively applied to skill acceptance model, where perceived value and effortlessness of use influence peoples' intention or judgment to admit. Generally, educational principle and norms, spiritual beliefs or even acquaintance would affect individual's perception about a meticulous thing which invariably decides his cause of action in future.

A cooperate housing developer whose intend is huge investment would be paying attention on return and repay back on the borrowed capital, security of the borrowed capital, associated risk, etc (Kuye, 2000). The real estate developer's behavioral manner and opinion toward these variables would affect his readiness and intent to borrow for funding landed property development. On the other hand, private individual developers' reflection is more often than not social (Udechuku, 2006; Kuye, 2000). Furthermore, these socio-cultural values, for instance, cultural norms, religious beliefs and knowledge have the influence of shaping developers' thoughts and view towards borrowing and its surrounding consequences- accessibility, interest rate and repayment period, thus influencing their judgment to borrow so as to finance their real estate developments.

From the abovementioned, there is a nexus been private residential developers' opinion on borrowing and the prolonged real property development problems in Nigeria and by connotation North Eastern Nigeria. It is against this background that this research seeks to evaluate the perception of private Real estate developers about borrowing and its attendant consequences as well as the potential of Sukuk as an alternative source of financing residential developments in North Eastern Nigeria.

\subsection{Statement of the Research Problem}

The call for development is invariable, for the reason that technology, population and taste by no means stop varying (Miles et al., 2007). This is factual of Nigeria with a projected population of almost 150 million people and twelve-monthly population increase rate of above 3.5\% (2006 Census). Nigerian present population statistic is expected to stand at nearly 160 million (NBS, 2012). Such variations require a foreseeable change in housing development to make available the accommodation need of the country. Nevertheless, there appears a disparity in prototype of changes with regards to these connected but inconsistent variables. Whereas population appears to vary in geometric order, housing development varies in Arithmetic proportion. This is noticed in the Nigeria housing shortage figure which is expected to stand at nearly 16million accommodation units (Udoekanem, 2012).

To balance this inconsistent state of affairs, enormous capital is essential to finance the shortage. Nigeria requires in any case N56trillion to build up minimum of 720,000 housing units annually over the subsequent 20years to meet up its accommodation needs (Udoekanem, 2012; cited FMBN, 2011). In the words of Ogunba (2009), Nigeria need amid $\$ 50$ trillion and $\$ 90$ trillion to finance its accommodation shortage. Presently, Nigeria requires N10trilion yearly over the subsequent five years to meet up the shelter needs of Nigerians (Chike-Obi, 2013). It is rather obvious that these extra-large sum could not be derived using the conventional source of finance bearing in mind the low per capital income of most Nigerians (Oganba, 2009), customary setting, and multifaceted macro economic situation (Ajibola et al., 2009). For that reason given that equity cannot offer the much desirable capital, conventional loan financing is necessary. Nonetheless, even the so called conventional or conformist borrowing which is anticipated to provide the requisite fund to finance housing development in Nigeria could not attain the projected success.

A large amount of this funding came from National Housing Fund (NHF) administered by Primary Mortgage Institution (PMIs), Federal Mortgage Bank of Nigeria (FMBN), Deposit Money Banks (DMBs), insurance companies and pension fund. Numerous studies recommended that these conservative or conventional means of financing housing development have not yet considerably played the function expected of them. This is typically credited to the interface of several problems, for instance, stringent repayment requirement, high interest rate, cumbersome loan requirement, inaccessibility, macro-economic environment and the likes (Ajibola et al., 2009; 
Aliyu et al., 2011; Sanusi, 2003; Ebie, 1998; Ibuoye, 2012; etc).

Based on the CBN (2010) report, the percentage allocation of loan or credit to landed property sector as at 2010 is about $8.7 \%$ of the total credit approved by pecuniary institutions in Nigeria. In addition, it is merely a fraction of this loan or credit that is dedicated to housing sector of landed property. Even the modern-day source of funding real property developments, which have realized great success in other nations, such as: Securitization, Real Estate Investment Trust (REITs), GDRs, debt conversion, mortgage backed securities etc; these means of financing have not up till now impacted greatly in funding housing development (Ajibola et al., 2009; Sanusi, 2003; Ire-Okili, 2012).

Even though quite a lot of studies have been carried out in the field of real property financing in Nigeria, such as Ajibola et al. (2009), Nubi (2000), Aliyu et al. (2011); Ogunba (2009), Ozili (2009), Udeomakin (2012), and others; a vital and important link is still missing. These studies have not reflected the fact that bulks of Nigerians who are made-up to be housed have no way in, at all, to financial institutions. Consequently, a good number of these studies failed to survey the prime causes of non-participation in the financial dealings by the majority Nigerians, as such cannot effectively provide the solution to the willful housing development financing dilemma and predicament in Nigeria. Based on the Africa (2013) report, which cited CBN head of corporate affairs department, Mr. Ugochukwo Okoafor, $65 \%$ of Nigerians have no way in to monetary institutions. In another account by research intelligence Magazine (2013), below 30\% of Nigerians have way in to financial structures. In a survey carried out for enhancing financial innovation and access (EFIA), (2012), only $32.5 \%$ of Nigerians officially secured for loan to build residential properties. Thus, there is missing gap between previous studies and housing development financing.

Nigerians are to certain degree religious and conformists. Religious doctrine, belief and societal norms could persuade peoples' choice to borrow from conventional means. As a matter of fact, the two major religious in Nigeria-Islam and Christianity discourage taking loan or borrowing with interest and deem or consider it offensive. Based on the Qur'an verses, Allah says:

“....they say 'trade is like usury', but God hath permitted trade and forbidden Usury”-Qur'an 2:274.

"Those who devour usury will not stand except as stands one whom the devil (Satan) by his touch has driven to madness. That is because they say, "trade is like usury', but Allah has permitted trade and has forbidden usury"$Q 2: 275$.

"Allah will deprive usury of all blessing and will give increase for deeds of charity, for he does not love any ungrateful sinner"-Q2:276.

"Oh you who believe! Fear Allah and give up what remains of demand for usury if you are indeed believers"Q2:278.

"If you do not, take notice of war from Allah and his messenger but if you repent you shall have your capital sum deal not unjustly and you shall not be dealt unjustly"- Q2:279.

Prophet Muhammad (pbuh) said, "Gold for gold, silver for silver, wheat for wheat, barley for barley, dates for dates, salt for salt - like for like, hand for hand. Whoever pays more to take more, indulges in Riba. The taker and giver are alike (in guilt)" (Sahih Al-Bukhari).

In the same vein, the bible also condemns lending and borrowing with interest:

"If you lend money to any of my people with you who is poor, you shall not be like a money lender to him and you shall not exact interest from him"- Exodus 22:25.

"You shall not charge interest on loan to your brother, interest on money, interest on food, interest on anything that is lent for interest"- Deuteronomy 23:19.

"Lends at interest, and takes profits (for food); shall he then live? He shall not live. He has done all these abominations; he shall surely die; his blood shall be upon himself"- Ezekiel 18:13.

There is tendency that these beliefs and ideas could influence and affect developers' discernment and intent to borrow from conventional means to finance housing development. Furthermore developers' cynicism and doubt in obtaining credit could influence and affect his judgment to apply for loan. Developers with investment ambitions perceive some factors which could influence and affect their choice to borrow from conventional means to finance housing development.

Yet, there is insufficient data and lack of empirical study to establish the validity of the aforementioned postulations. Hence, it is within this background that this study tends to answer: how does the developers' 
judgment and perception concerning conventional borrowing affect and influence their choice and decision to obtain loan or borrow in financing housing development in North Eastern Nigeria? The purpose of this research is, therefore to evaluate the existing literature on the perception of real estate developers of conventional borrowing in financing residential developments with a view to explore the potentials of Sukuk as an alternative source of financing residential development in North Eastern Nigeria. If the research is completed, it will answer the following questions: What are the socio-economic characteristics of residential real estate developers? What are the performances of conventional lending institutions in financing residential development? What are the developers' perception about borrowing and its attendant consequences? How does developers' perception of conventional borrowing influence their willingness and intention to borrow in financing residential development? How would Sukuk serve as a potential alternative source of financing Residential Developments in North Eastern Nigeria?

\subsection{Scope and Delimitation of the Research}

This study covers conventional lending institutions and private residential developers in North Eastern Nigeria. For the purpose of this research, private residential developers include property development companies, estate surveyors and valuers consultancy firms who engage in real property development, and private individuals who built residential apartments in the last 5 years occupancy purpose. This research is bordered and delimited to residential accommodation aspect of real estate development and evaluated only the conventional source of financing real estate development.

\subsection{Significance/Practical Implication of the Research}

This research would have the following implications:

1) The research would enable policy makers to review the real estate financing policy to reflect the yearning and aspiration of the citizens. This would ensure an all inclusive policy that accommodates the different and diverse opinion, perception and beliefs of the populace.

2) The research would provide a framework and universal remedy to the apparently intractable problems of residential development financing.

3) The research would provide the avenue for potential investors to tap from the unutilized opportunity as it would reveal the prospect of Sukuk as an alternative means of financing residential development in North Eastern Nigeria.

4) The research would provide investors and developers in residential market with basis to compare between the conventional financing scheme and the proposed; this enables them to take decisions that ensure maximum return on investment, minimal risk and immunity to their socio-cultural norms.

5) The research would also bridge a gap in knowledge by bringing forward the application of theory of planned behavior and acceptance model into residential development financing. The influence of belief on perception and attitude which influence decision to borrow in financing residential development is an important factor in financing development which past research effort failed to capture.

\section{Review of Emerging Literature}

\subsection{Past Studies on Real Property Development}

Landed property is an essential asset to any nation. As asserted by Ire-Okoli (2012), it means the property comprising of land and buildings on it, alongside with its natural resources. Lawal (2000) looked at it as a physical or corporeal land appurtenance, together with structures attached there to. On the other hand, Belts and Ely (2005) differentiated real estate or landed property as physical or material objects (land and buildings) from real property which is the right obtained or held to the elimination of others. At any rate, real estate is an important factor in man's fruition. The path in the course of which this vital asset is attained is development. Development been the course of action of executing construction work by means of an alteration, change or modification in land use or land through its buildings, or by way of change in the concentration of the utilization of land or by means of re-establishment of current use (Lawal, 2000); it is taking place to offer lodging for living for the individual executing the development or someone as well (Nuhu, 2007), and other ventures or investment considerations.

Real property development provides a foundation for nation's fiscal development and arouses further sectors of the country in the course of its multiplier effect. Ire-Okoli (2012), who quoted Fuller (2005), put forward that real property development impact straight on the instantaneous environment all the way through multiplicity of employment creation, increases the acquisition power of locals by the side of the building state, arouse growth 
and development of supplementary industries and discharge funds for more developments and venture or investment, draw capital inflow hooked on the country's economy, thus contributing to economy's Gross Domestic Product (GDP). Due to the significance of this asset, Johnson (2006) buttresses that landed property account for about two third of nationwide wealth of United States of America and more than $25 \%$ of the Gross Domestic Product (GDP). He as well stressed that professionals have identified real property as the leading holding for a huge percentage of family unit in the United State of America.

One vital aspect of real property is the housing accommodation sector. This is mostly important for the reason that social undertone is attached to it. It presents one of the indispensable needs and demands of mankind, that is housing (Abd Aziz, Hanif, \& Singaravello, 2011; Majale, 2004; Adedeji \& Olutuoh, 2012; Folurunso, Khan, \& Olowoyo, 2012; and others). Provision of this necessary product has been a capital demanding and requires enormous finance. Foo (2000) argued that the gaining of real property asset involves huge capital outlay, which is in the majority cases beyond the accomplishment of small investors. Agedengbe and Adesopo (2003) are of the opinion that residential development entails enormous capital expenditure. They, consequently, argued that finance makes up an essential center piece in several real property developments and an all central factor, a sine-quanom and incredibly crucial component to projects regardless of their nature. Adedeji and Olutuoh (2012) confirmed the above contention when they conceive that finance is a most imperative factor in accommodation delivery. Finance shapes the timing, scale of operation, phasing and marketing strategy for the end product (Ajibola et al., 2009).

\subsection{Studies on Sources of Financing Landed Property Development}

Finance for housing development is obtained in diverse ways. While Ajibola et al. (2009) classified the sources of getting finance for housing development into conventional (traditional) and contemporary (modern) sources; Ibuoye (2009) classified them into Traditional and Modern source. Conversely, Jinadu (2007) grouped it into public and private sources of financing housing development. Regardless of how the source is labeled; it is either equity, in one hand or money owing (borrowing) sources. Equity entails finance accrued internally from person personal savings. By tradition, people raise money for housing development via traditional sources such as 'Asusu', 'Adashe', and 'Ajo'. Later on, people raise money through individual and family savings (Adedeji \& Olutuoh, 2012). Even though this means of financing plays a significant role in financing housing development, it has confirmed inadequate ultimately. This is apparent in the reality that the majority Nigerians gets extremely low income matches up to their contemporaries in other economies (Ogunba, 2009). Nevertheless, Ajibola et al, (2012) ascribed this to the nature of traditional background and the multifaceted macro-economic state of affairs. In view of the fact that equity or fair play capital could not offer the greatly needed finance, residential developers have to opt for credit. Nevertheless, even if equity or fairness is sufficient for the property development, additional considerations proliferate that support and justify borrowing or obtaining loan. Alile (2005) is of the belief that for an investor to expand and diversify investment or venture and trim down the general port folio danger or risk, it may perhaps be prudent to commit barely a portion of the obtainable equity fund or capital. He, moreover, contended that, in as much as interest rate is lesser than the predictable debt-free benefit or return, the rate or pace of return or payback on the injected or invested capital sum would be greater. This finance is obtained and borrowed through conventional and financial banking institutions such as credit or mortgage institutions, insurance companies, money deposit banks, and pension fund. These financial institutions offer fund to residential developers in the form of mortgage loans.

Credit or mortgage financing is a dedicated type of credit or loan transaction concerning the giving way of long term credit finance for home development. The most important institutions that give this loan financing in Nigeria include the federal mortgage bank of Nigeria (FMBN) which control the actions of primary mortgage institutions (PMIs) and manage the National Housing Fund; Money deposit banking institutions which were previously the merchant banks, commercial banks and insurance companies. Primary Mortgage Institutions (PMIs) are financial and monetary intermediaries and mediators in the accommodation finance sector, having unique legal character as preserve in its enabling ruling, decree No.53 of 1989, to encourage saving from the public or community and grant or offer housing loans to individuals, while federal mortgage bank of Nigeria (FMBN) mobilize funds to augment private sector involvement in housing finance (Adedokun et al., 2012).

To reinforce the role of PMIs to make money obtainable for housing development, the National Housing Fund (NHF) was recognized. The intend of the finance, according to Ozili (2009) is to boost the supply of credit funds and thus insulate the home finance system from the condition of insufficient long term finance that had delayed the expansion and growth of the lending or credit services through compulsory regular contribution. This finances have legal backing or support by virtue of established decree No.3 of 1992 (now an act) to particularly nurture and maintain steady base for reasonable housing finance. The NHF is managed by FMBN through 
registration, mobilization, refund, issuance, pass book, collection, and mortgage lending by means of multiple window of admittance concerning Primary Mortgage Institutions (PMIs) and residential property developers.

Contribution or donation to NHF, as enshrined in section 6 and 5 of NHF (1992) normally comes from the federal government, commercial banks (now money or finance deposit banks) and insurance companies respectively. Section 6 of the decree entail FGN to make sufficient financial contribution or donation to the fund; whilst section 5 consented banks to donate $10 \%$ of its reserved loan and advances at a required interest rate of $1 \%$ which is above interest rate owed on most current accounts by banks; whereas registered insurance companies are obligated to give a bare minimum of $20 \%$ of its non life finances and $40 \%$ of its life finances in real property development of which not below 50\% shall be remunerated into the fund via FMBN at an interest rate not more than $4 \%$. The legislation as well requires each Nigerian that is earning an income of $\$ 3000$ and beyond to give $2.5 \%$ of his income or earning to the fund.

Ozili (2009) reported that the FMBN is mandated to ensure that advance from NHF are utilized for housing by means of wholesale, mortgage loans giving to Primary Mortgage Institutions (PMIs) and real estate developers. Though, in spite of the impact of this monetary sector, housing or home finance via it has been insignificant. Folurunsu et al. (2012), who cited Lemo (2007), revealed that prior to the year 2007, from the beginning of home finance system in Nigeria, barely a worthless sum of nearly $\$ 70$ billion have been pumped to the system. It account for below $0.5 \%$ of GDP. Another study by Ogunba (2009) on improving lodging fund modeling; stated that the National Housing Fund (NHF) do not make substantial impact on housing or home financing.

\subsection{Studies on Interest Charged by Financial Lending Institutions}

In another study by Agedengbe and Adesopo (2003), they revealed that the interests charged by financial institutions are more often than not very high. Udoekanem (2012) opined that mortgage finance institutions in Nigeria have not positively impacted considerably to affordable home financing owing to high interest rate charged by obtainable borrowed funds which are unattainable by virtually low and middle income category or groups. Ogunba (2009) buttressed the malfunction of NHF directed through PMIs grounded by problems ranging from meager contributions to the finance, the demand for collateral securities, inadequate number and deprived stretch of primary mortgage institutions, lack of access by PMIs to the housing fund and low affordability limits of prospective borrowers. In another study by Adedokun (2012), he affirmed that further than 3,447,482 contributors or donators to the NHF, barely 44,788 which symbolize $1.30 \%$ have only benefited from the system or scheme while $98.7 \%$ are until now not benefited from the similar scheme. He subsequently concluded that compared to the objective or target of the finance, the fund witness only $0.22 \%$ achievement.

Moreover, Money Deposit Banks (MDBs) are trade bankers by business operation. They give out on short term basis as they have to meet up with the withdrawal demand and request at the shortest take in. Money deposit banks fall short of providing the most required finance for housing development. This is as a result that home finance needs long term finance (Emoh \& Nwachuckwu, 2012). Due to penchant for higher income or yield, the Nigerian pension funds and insurance industry failed to play significant and important role in home finance (Nubi, 2000). In the words of Sanusi (2003), the low and negligible interest rate on lodging fund make insurance companies and banks reluctant and unwilling to invest and spend in the fund particularly as there are a number of investments that seemed to be more gainful and profitable compare to investing in housing.

Conventional borrowing was found to be insufficient in financing housing developments in Nigeria. The malfunction of the conventional means necessitates the urge for alternative means of finance such as unitization, securitization as well as Real Estate Investment Trust (REITs) (Ajibola et al., 2009).

\subsection{Securitization as a Means of Financing Real Estate Development}

Securitization is the method of converting and changing an asset, in the vein of real estate, into notes and revolving same into tradable device with the fundamental asset as security. It concerned with the changing and conversion of asset into gladly tradable asset, that is, securities (Ajibola et al., 2012; Breidenbach, 2003; Nubi, 2000). As pointed by Joshi (2011), securitization is a procedure whereby a corporation packages its assets hooked on securities and disposes them to investors. The key difference stuck between traditional mortgages backed, also known as collaterized loan arrangement and securitization (ABS) is the division or off-the-balance-sheet transfer of rights and possessions of landed property to special purpose vehicle (SPV). The alternative to securitization is unitization. Unitization has to do with the creation and introduction of numerous shares in the possession and ownership of a single property; the shares offer an opportunity for poor and low income earners to partake in co-ownership of prime and major properties (Olawande, 2012).

Securitization plays a very important role in landed property financing. It helped out in the growth of realty 
market world over as key banks. Other financial institutions considered that through securitizing their assets particularly mortgages, they will be able to endure sub-prime risks except there is no opposing fact that securitization in addition to helping them in enhancing their non-fee based revenue through expanding their investment collection which if not would not be promising owing to illiquidity (Joshi, 2011). By Foo (2000)'s evaluation, asset securitization contributed significantly to landed property in Singapore. Furthermore, in the United Kingdom, unitization medium such as single property ownership trust (SPOT), solitary property company (SOPCO), and property income certificates (PINCs) have been initiated to facilitate and help investor to engage in the equity interest of capital and rental value performance of a real property. Moreover, in the United State, the comparable vehicles such as real estate investment trust (REITs), MBS and ABS are as well formed for securitizing illiquid landed property (Foo, 2000).

\subsection{Real Estate Investment Trust as a Catalyst for Housing Development}

Real estate investment trust (REIT) is a trust or corporation that unites the capital of numerous investors to obtain or offer financing for all types of real estate (Ajibola et al., 2009). In Nigeria today, the investment and securities act (2007) referred REITs as a landed property investment trust or companies as a body corporate included for the solitary purpose of obtaining intermediate and long term interest in realty or property development. This is important in providing the essential fund needed for financing housing development. Alile (2005) established that there are over 300 widely traded REITs working in the United State where the make use of REITs increased to \$34billion in the first quarter of 2004. In Nigeria, there has been a shift in the introduction of REITs for financing huge scale property development. However, as at 2004, only one landed property development company UACN has been listed in the Nigeria stock exchange market and account for about N8billion of the marketplace capitalization of the exchange (Alile, 2005).

In his concluding remark, Sanusi (2003) suggested that:

"New source of housing fund should be explored through development of a variety of instruments for the mobilization of funds from capital market. This include large scale securitization of mortgage portfolio, a mechanism that has remained the primary engine growth in the housing finance system of US, Germany, France, and Italy to name only a few. For example, the national housing fund in South Korea thrives on, not only on the deposit subscription, but also housing bonds issued by the housing bank to finance housing development programmes. Therefore, broadening the capital market to encourage sales and exchange of housing related securities can generate additional leverage......"

Corroborating Sanusi (2003)'s stand, Alile (2005) posits that:

"......despite the shift in real estate financing under which developers increasingly resort to borrowing, activity is still constrained by high costs of financing from the banks, which because of the short term nature of their deposits have largely proved unsupportive to the industry.... Therefore, industry operators cannot overlook elsewhere for the financing required driving the sector to the desired growth direction. Long term debt and equity financing as are obtainable in the capital market, will certainly allow developers to considerably reduce cost of finance n return for sharing investment income...."

Nevertheless, notwithstanding the arguments concerning the significance of the modern source of financing housing development all over the world, the means of finance has not played any important role in making available the much needed fund in Nigeria. This is obvious in the findings of Ajibola et al. (2009) in which he revealed that even though contemporary means and sources have sufficiently meet the capital obligation in developed nations, it is nevertheless unpopular and insufficient in Nigeria.

\subsection{Theory of the Acceptance Model and Planned Behavior}

The preceding review corroborate why dwelling ownership in Nigeria is put at $25 \%$ compare to $72 \%$ US, $78 \%$ UK, $60 \%$ China, 54\% Korea (Onyike, 2009). This imposed the need for searching of another alternative means or source of financing housing development. In spite of these challenges, nothing or little has been understood about the discernment of developers as regards borrowing in Nigeria. Hence, the theory of the acceptance model and planned behavior aid in understanding the association between attitude, perception and the intention to carry out a given action as well. It is effectively applied in other fields, particularly ICT, in ascertaining the willingness or intention to buy or use a given thing bearing in mind the belief, attitude and behavioral construct of the concerned person (Singh et al., 2010; Saade et al., 2007).

As asserted by Ajzen (2002), theory and presumption of planned behavior is directed and guided purely by three considerations; control belief, normative belief and behavioral belief. In combination, subjective norms, attitude toward the behavior and the perception or discernment of behavioral control culminated into the formation of 
behavioral meaning or intention. Generally, the more constructive the subjective norm, attitude and the better perceived control, the stronger should be the individual's intention to carry out the action under consideration. A study conducted by Chiou (1998) revealed that the relative significance of subjective norm, attitude as well as perceived behavioral control forecast the intention of persons and varies when individual possess various level of subjective or slanted product knowledge.

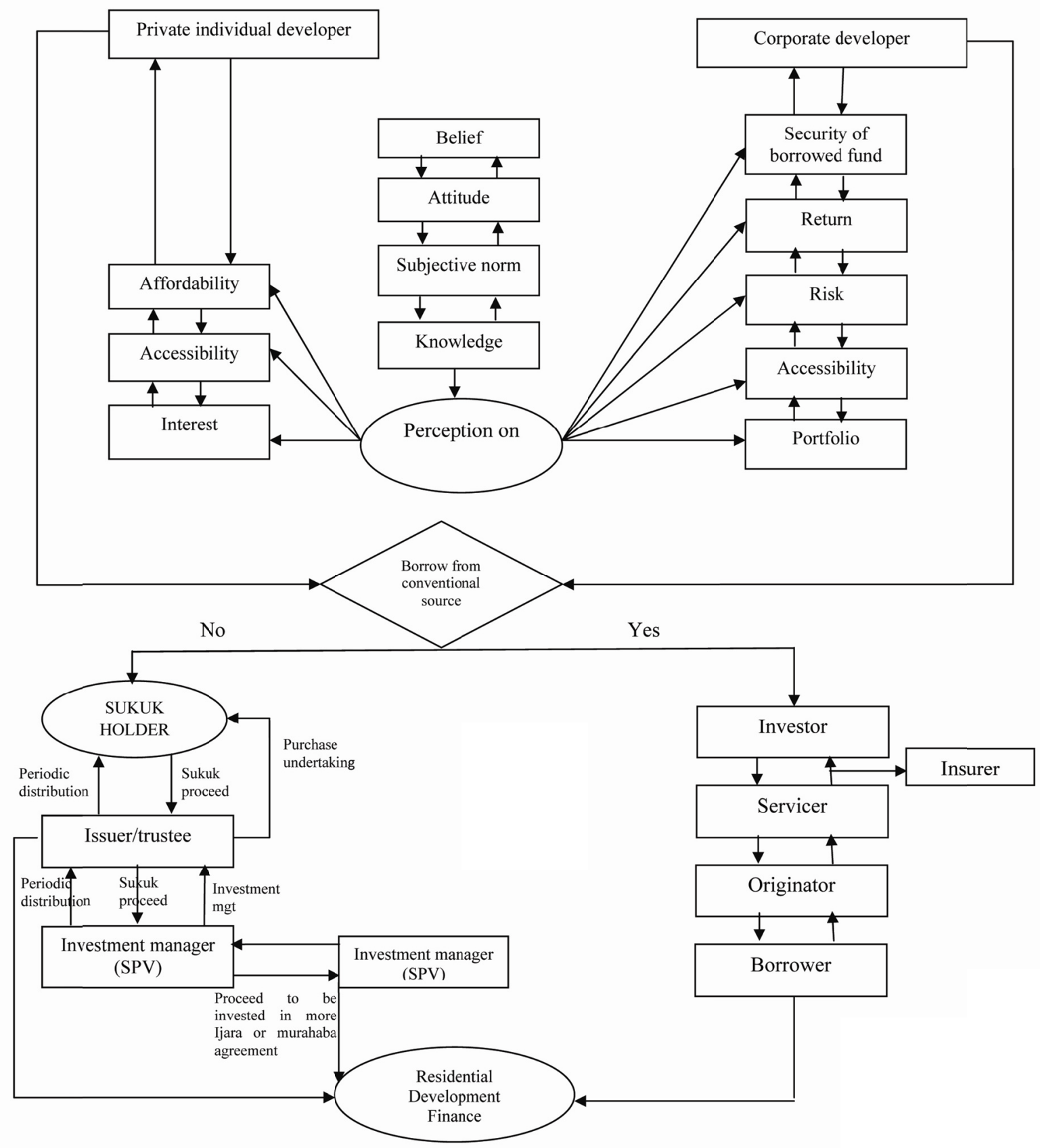

Source: Author (2014).

The theory or postulation could facilitate in solving the intricacies and problems of housing development bearing in mind the influence that attitude, belief, and norm might have on the perception and opinion of the property developer and his intent to have a loan for financing housing development. Taking into consideration the socio-cultural background of Nigeria where culture and religion are given paramount priority, the decision and judgment of housing developers could be influenced or affected by the prohibition of mainly borrowing 
conditions connected with conventional loan or borrowing. Recognizing these assortments in Nigeria, the Central Bank of Nigeria (CBN) in 2011 issued the guidelines and procedure for the supervision and regulation of institution giving out non-interest (Islamic Banking) monetary services in Nigeria.

According to the guiding principle, Islamic Banking is an interest free banking which provides the same function of providing monetary services put away that it operates in line with rules and principles of Islamic money-making jurisprudence that by and large identifies profits and loss allotment and the ban or prohibition of interest. The guideline is coined and developed based on the growing number of demand from individuals, banks and other financial establishments willing to offer non-interest banking in accordance with Islamic profit-making jurisprudence in Nigeria.

Adebayo (2011) buttressed that owing to opinions raised from different quarters alongside the exploitation, flows and short comings of the conventional or conservative financial system, there is an utmost need for monetary system devoid of manipulative tendencies in the previous system. An important facet of Islamic Finance or business has been the incorporation of mortgage products for accommodation finance (Tameme, 2009). For example, Amin (2008) stated that Islamic banking industry has impacted positively in building a vivacious Islamic financial market as well as offering a variety of products which are Sharia-complaints encompassing insurance, mortgages and the likes.

One of the significant instruments in Islamic business is the Sukuk. According to Zin et al. (2011), Islamic finance has been on the increase at an average rate of above $30 \%$ per annum, and Sukuk (Islamic bond) is amid the most flourishing Islamic financial merchandise in the industry and one of the highest growing segments in the international financial landscape. Numerous studies and researches have proved the significance of Sukuk in providing the much needed fund for quite long term investments (Wijnbergen \& Zaheer, 2013; IFSB, 2009; Rating Direct, 2013; Aziz, 2013; Wilson \& Al-Amine, 2008 and others).

Sukuk is an official document of equal value that signifies an undivided and unbroken interest (relative to investor's interest) in the ownership and possession of an essential asset. Thus, Sukuk could eventually fill the gap caused by inadequate long-standing conventional financing which are forbidden under Sharia for the reason of interest. A study carried out by Sulaiman (2012) revealed that Sukuk plays a significant role in financing landed property development. He cited the victory story of Dar Al-Arkan landed property company whose commitment in Sukuk yielded the company momentous success in its business undertaken. The literature review validates the need for this study.

\section{Theoretical and Conceptual Framework}

\subsection{Proposed Conceptual Framework}

The proposed framework is a product, modified by the researcher, of the theory of planned behavior, mortgage financing and Sukuk structure partly adopted from Ajzen (2002), Ibuoye (2009) and Sulaiman (2012) respectively. The proposed framework is adopted to guide the researcher.

\section{Findings from the Extensive Review of Related Literature}

Based on the extensive review of previous literature, the following findings were established

1) A good number of developers have little experience on residential development technicalities as their level of education, awareness and expertise are low.

2) The income of most real estate developers is relatively low; consequently cannot afford high interest rate charged by conventional lending institutions.

3) The performance and functions of lending institution are very low in financing housing developments in the study area as discovered in the past studies.

4) Developers perceived borrowing as weakness.

5) Socio-cultural beliefs attitudes, viewpoints, ideas, thinking and religion influence developers' perception on borrowing and considers it as repulsive or abomination; thus affect their willingness readiness to borrow for financing housing development.

6) Perception about return or benefit on investment and associated risks affect corporate real estate developers' willingness or eagerness to borrow.

7) There is momentous relationship between landed property developers' perception and awareness on borrowing and its attendant consequences and their intention or willingness to borrow in financing housing development. 
8) Developers would have very high and significant preference or choice to Sukuk financing when introduced.

9) There is significant dissimilarity between developers' preference to Sukuk and conventional or conservative lending in financing real estate developments.

\section{Possible Recommendation}

1) Government should review and appraise its housing financing policy to reflect the assortment of its citizen and to provide every citizen with a sense of belonging. This would make certain an even access to real estate development finance to all and sundry.

2) The overall macro-economic situation should be improved. This would have a multiplier consequence on individual household leading to increase in income, thus encourage higher propensity or tendency to save than to consume. This would improve the affordability level.

3) The conventional lending banking institution should improve on their performance in financing real estate development through compromising their ever stringent and rigorous requirement, such as certificate of occupancy, high interest, short term refunding and the likes.

4) Investors should tap from the unutilized opportunity and possibility of higher preference to Sukuk in financing real estate development.

5) The Nigerian stock exchange commission (SEC), as a matter of exigency or urgency, should provide the essential legal and regulatory framework for the issuance of Sukuk in the Nigerian Exchange Market.

6) The Commercial Banks, as enshrined by CBN non-interest banking regulatory framework, (2011) should utilized the opportunity of operating a window in Islamic banking financing and direct or channel more fund to real estate development financing.

\section{Conclusion}

Finance or fund has been regarded the most essential instrument in the development of one of the tripartite basic necessity of mankind, that is housing. Housing development is at all times very complex beyond the income or reach of many prospective landed property developers; therefore necessitating the requirement for borrowing to finance the discrepancy or deficit. Nevertheless, even the borrowing is still insufficient in financing housing development.

Bearing in mind the socio-economic and religious setting, one cannot discard the possibility or tendency of these factors influencing or affecting the cognitive altitude of the real estate developer towards borrowing. Furthermore, taking into account the fact that interest on borrowing is disliked by both Islam and Christianity, most real estate developers succumb to this influence and keep away from borrowing from conventional sources. With the introduction of non-interest banking in Nigeria, hope abounds that preponderance of Nigeria, deterred from conventional banking owing to aforementioned fact, and would benefit from the gesticulation in financing housing development particularly if Sukuk is fully or completely developed in Nigeria.

\section{Acknowledgments}

Special appreciation goes to my mentors, Assoc. Prof. Dr. Rozilah Binti Kasim and Assoc. Prof. Dr. David Martin of Tun Hussein Onn University of Malaysia for their painstaking in proof-reading the manuscript. I appreciate their understanding and unwavering support in the conduct of this research. Moreover, I am equally thankful to my employer, Abubakar Tafawa Balewa University, Bauchi who funded the research.

I wish to express my gratitude to my colleagues who always stood by my side to make sure that the manuscript is published in referred and reputable journal. Their tireless effort deserves to be mentioned in this regard. I am equally grateful to my senior colleagues both at Abubakar Tafawa Balewa University, Bauchi and Tun Hussein Onn University of Malaysia as they provided useful and vital comments, observations, suggestions and critique in the process of writing this article. To all these people and organizations, I say a big thanks.

\section{References}

Abd Aziz, W. N., Hanif, N. R., \& Singaravello, K. (2011). A Study of Affordable Housing within the Middle Income Households in the Major Cities and Towns of Malaysia. Australian Journal of Basic and Applied Sciences, 5(8), 258-267.

Adebayo, R. I. (2011). A Study of the Legal and Regulatory Issues of Non-Interest Banking System in Nigeria. Journal of Islamic Banking and Finance, 28(1).

Adedeji, Y. M. D., \& Olotuah, A. O. (2012). An Evaluation of Accessibility of Low-Income Earners to Housing 
Finance in Nigeria. American-Eurasian Journal of Scientific Research, 7(1), 23-31.

Adedokun, O. A., Akinradewo, F. O., Adegoke, J. O., \& Abiola-Falemo, J. O. (2012). Evaluation of the Contribution of Nation Housing Fund towards Housing Delivery in Nigeria. Journal of Building Performance, 3(1).

Agedengbe, P. S., \& Adesopo, A. A. (2003). Problems of Financing Real Estate Development in Nigeria. Journal of Humanitarian and Ecology, 14(6), 426-431.

Ajibola, M. O., Oloyede, S. A., \& Oni, A. O. (2009). Real Estate Investment Trust: An Attractive Vehicle for Real Estate Development in Nigeria. The Estate Surveyor and Valuer, 32(1), 60-66.

Ajzen, I. (2002). Constructing a TpB questionnaire: Conceptual and methodological considerations. Retrieved from http://www.uni-bielefed.de/ikg/zick/ajzen

Al-Amine, M. A. M. (2008). Sukuk Market: Innovations and Challenges. Islamic Economic Studies, 15(2).

Alile, H. I. (2005). The Development of Real Estate Industry, the Role of the Capital Market: An Alternative Financing Framework. Ethical Behavior and Practice of Estate Surveyors and Valuers, John Wood Ekpeyong Annual Memorial Lecture Series. Compilation of NIEVS 2006.

Aliyu, A. A., Kasim, R., \& Martin, D. (2011). Factors Affecting Housing Development in Makama Jahun Area of Bauchi Metropolis, Nigeria. International Journal of Trade, Economics and Finance, 2(4).

All Africa. (2013). Nigeria: 65\% of Nigerians have no Access to Financial Institutions-CBN. Retrieved from http://m.allafrica.com/stories/201303110286.html/

Amin. (2008). Choice Criteria for Islamic Financing: Empirical Investigation among Malaysian Bank Customers. International Journal of Housing Markets and Analysis, 1(3), 256-274.

Aziz, Z. A. (2013). Regulatory and Governance for Islamic Finance. Speech Presented at the Brunei Darussalam Islamic Investment Summit 2013. Bandar Begawan, Brunei, 19th June.

Belts, R. M., \& Ely, S. J. (2005). Basic Real Estate Appraisal. US: Thompson South Western.

Breidenbach, M. (2003). Real Estate Securitization as an Alternative Source of Financing for Property Industry. A Paper Presented at the 9th Annual Conference of Pacific Rim Real Estate Society Held at Brisbane, Australia, 19th-22nd January.

CBN. (2010). $2010 \quad$ Annual $\quad$ Report. $\quad$ Retrieved from http://www.cenbank.org/out/2011/publications/cbn\%20annual\%20report\%202010\%20pdf

CBN. (2011). Guidelines for the Regulation and Supervision of Institutions Offering Non-Interest Financial Services in Nigeria. Retrieved from http://www.cenbank.org/out/2011/pressrelease

Chike-OBI, M. (2013). Housing Finance: Stakeholders Query Mortgage Refinance Company's Role. Retrieved from http://www.punchng.com/business/homes-propery/housing-finance-stakeholders-query

Chiou, J. (1998). The Effect of Attitude, Subjective Norm, and Perceived Behavioral Control on Consumers' Purchase Intention: The Moderating Effects of Product Knowledge and Attention to Social comparison Information. National Science Council, 9(2), 298-308.

Ebie, S. P. O. (1998). Go Do Like-Wise. A Paper Presented at the 4th J. W. Ekpeyong Annual Memorial Lecture Held at Lagos, 4th February, 1998.

Emoh, F. I., \& Nwachucku, C. C. (2011). Critical Issues in Real Estate Finance as an Index in Building Construction Project Management Success in Nigeria. American Journal of Social and Management Sciences, 2(1), 76-90.

Enhancing Financial Innovation and Access (EFinA). (2012). Survey. Retrieved from http://www.efina.org.ng/assets/documents/

Federal Government of Nigeria. (1992). National Housing Fund Decree. Government Publishers, Abuja.

Folurunso, C. O., Khan, T. H., \& Olowoyo, S. A. (2012). Trends, Realities and Prospect of Housing Delivery through Mortgage Financing in Nigeria. British Journal of Arts and Sciences, 7(II).

Foo, S. T. (2000). Securitizing Real Estate-A Primer on the New Financial Instrument. Department of Real Estate, National University of Singapore.

Ibuoye, A. A. (2009). Mortgage Financing as a Veritable to Enhance Mass Housing Finance. Paper Presented at 39th Annual Conference of the Nigeria Institution of Estate Surveyors and Valuers, held at Anambara 


\section{1-26th April.}

IFSB. (2009). Capital Adequacy Requirement for Sukuk, Securitization and Real Estate Investment. Retrieved from http://www.ifsb.org

Ire-Okoli, C. R. (2012). Transforming Nigeria's Economy through Real Estate Development. A Paper Presented at the 42nd Annual Conference of the Nigeria Institution of Estate Surveyors and Valuers Held at Transcorp Hilton hotel, Abuja, 20th-24th March.

Jinadu, A. M. (2007). Understanding the Basics of Housing. Revised Edition, Minna: King James Publishers.

Johnson, D. T. (2006). Real Estate Investing. Managerial Finance, 32(12), 953-964.

Joshi, V. (2011). Securitization and its Relationship with Real Estate Growth-An Analysis. International Journal of Research in Commerce, Economics and Management, 1(5).

Kuye, O. (2000). Property Valuation Principle and Practice in Nigeria. Lagos: Nigeria National library cataloguing in publication data.

Lawal, M. I. (2000). Estate Development Practice in Nigeria. Lagos: ILCO Books and Publishers.

Majale, M. (2004). Improving Access to Adequate and Affordable Housing for the Urban Poor through Integrated Approach. A Paper Presented at International Conference of Adequate and Affordable Housing for All, Toronto, June 24-27.

Miles, M. E., Berens, G. L., Epph, M. J., \& Weiss, A. M. (2007). Real Estate Development and Process. Washington: Urban Land Institute.

Monlezuma, J. (2004). Housing Investment in an Institutional Portfolio Context: A Review of the Issue. Property Management, 22, 230-249.

National Population Census. (2006).

NBS. (2009). Social Statistics in Nigeria. Retrieved from http://www.nigeriastat.gov.ng

NBS. (2012). Abstract of Statistics. Retrieved from http://www.nigeriastat.gov.ng

Nubi, T. O. (2000). Housing Finance in Nigeria: Need for Re-Engineering. Department of Estate Management, University of Lagos.

Nuhu, M. B. (2007). Property Development as A Panacea to Poverty Alleviation in Nigeria. Hong Kong: TS 5G Affordable and Sustainable Development, Strategic Integration of Surveying Services.

Ogbonna, A. C. (2012). Vision 202020 and the Transformation Agenda: Towards a Modified Direct Intervention Framework for Housing Using the $(L 4 C+S S+I) / P$ Partnering Combination Model. A Paper Presented at the 42nd Annual Conference of the Nigeria Institution of Estate Surveyors and Valuers Held at Transcorp Hilton hotel, Abuja, 20th-24th March.

Ogunba, O. A. (2009). Improving Housing Fund Modeling in Nigeria: Lessons from US and China Models. The Estate Surveyor and Valuer, 32(1), 51-59.

Olawande, O. A. (2012). The Impact of Money Market Indicators on Real Estate Finance in Nigeria. A Paper Presented at the 42nd Annual Conference of the Nigeria Institution of Estate Surveyors and Valuers Held at Transcorp Hilton hotel, Abuja, 20th-24th March.

Olurotimi, K. (2009). Housing the Physically Challenged People in Nigeria: the Challenges and Way Forward. Paper presented at 39th Annual Conference of the Nigeria Institution of Estate Surveyors and Valuers, held at Anambara 21st-26 April.

Onyike, J. A. (2009). The Urban Problem of Nigeria in the 21st Century. Paper Presented At $39^{\text {th }}$ Annual Conference of the Nigeria Institution of Estate Surveyors and Valuers, held at Anambara 21st-26 April.

Ozili, P. C. (2009). A Critique of National Housing Fund Scheme in Nigeria. Paper Presented at $39^{\text {th }}$ Annual Conference of the Nigeria Institution of Estate Surveyors and Valuers, held at Anambara $21^{\text {st }}-26$ April.

Ratings Directs. (2013). Investors' Appetite is Pushing Sukuk into Main Stream. Retrieved from http://www.standardandpoors.com/ratingdirect

Research Intelligence Magazine. (2013). Less than 30\% of Nigerians have Access to Financial InstitutionsNewman. Retrieved from http://www.research-intelligencemagazine.com/mj/index.php?option

Saade, R. G., Nabebe, F., \& Tan, W. (2007). Viability of technology acceptance model in multimedia learning 
environments: A comparative study. Interdisciplinary Journal of Knowledge and Learning Objects, 3.

Sanusi, J. O. (2003). Mortgage Financing: Issues and challenges. A paper presented at the 9th John Wood Ekpeyong organized by Nigeria Institution of Estate surveyors and Valuers, January, 29.

Singh, S., Singh, D. K., Singh, M. K., \& Singh, S. K. (2010). The Forecasting of 3G Market in India Based on Revised Technology Acceptance Model. International Journal of Next Generation Networks (IJNGN), 2(2).

Sulaiman, A. K. (2012). Sukuk Issuance in Saudi Arabia: Recent Trends and Positive Expectations. Durham e-theses, Durham University. Retrieved from http://etheses.dur.ac.uk/3502/

Tameme, M. E. M. (2009). Demand and Supply Condition of Islamic Housing Finance in the United Kingdom: Perception of Muslim Clients. Durham e-theses, Durham University. Retrieved from http://etheses.dur.ac.uk/77/

The Investment and Securities Act. (2007). Retrieved from http://www.sec.gov.ng/files/the\%20investment\%20and\%20securities\%20act....pdf.

Udechuckwu, C. (2006). Introduction to Estate Management. Lagos: Treem Ltd.

Udo-Akagha, S. (2000). So the Year 2000 is Here. Ethical Behavior and Practice of Estate Surveyors and Valuers, John Wood Ekpeyong Annual Memorial Lecture Series, Compilation of NIEVS 2006.

Udoekanem, N. B. (2012). The Performance of Mortgage Institutions in Achieving Affordable Housing Financing in Niger State, Nigeria. The Estate Surveyor and Valuer, 36(2).

Wijnbergen, S. V., \& Zaheer, S. (2013). Sukuk Defaults: On Distress Resolution in Islamic Finance. Tinbergen Institute Discussion Paper. Retrieved from http://www.timbergen.nl

Wilson, R. (n. d.). Islamic bond: Your Guide to Issuing, Structuring and Investing in Sukuk. Euromoney Institutional Investors plc. Retrieved from http://www.euromoneybooks.com

Zin, M. Z. M., Hashim, N., Khalid, N. K., Opir, H., \& Sulaiman, R. (2011). The Implementation of Sukuk in Islamic Finance. International Conference on Society and Economic Development, 10.

\section{Copyrights}

Copyright for this article is retained by the author(s), with first publication rights granted to the journal.

This is an open-access article distributed under the terms and conditions of the Creative Commons Attribution license (http://creativecommons.org/licenses/by/3.0/). 